\title{
G.M. PELLISSIER OOR DIE PREDIKING
}

\section{A.J. SMUTS}

In 'n sekere sin kan professor Pellissier die vader van die teologiese fakulteit van die Ned. Geref. Kerk aan die Universiteit van Pretoria genoem word. George Murray Pellissier was naamlik die eerste en vir vier jaar lank die enigste professor van die Ned. Geref. Kerk in die teologiese fakulteit aan die Universiteit van Pretoria. In 1934 - tans al meer as 'n halwe eeu gelede - is hy aangestel as professor in die teologiese fakulteit. Sy taak was om as enigste dosent van die Ned. Geref. Kerk in 'n fakulteit wat reeds ' $n$ hele aantal jare lank predikante van die Ned. Herv. Kerk opgelei het en beman was deur professore van hierdie kerk, die opleiding van die kandidate van die Ned. Geref. Kerk te behartig. Slegs een student het hiervan gebruik gemaak. In hierdie sleutelposisie het Pellissier egter ' $n$ belangrike rol gespeel in die totstandkoming van ' $n$ afsonderlike afdeling van die teologiese fakulteit, waar 'n volwaardige opleiding vir predikante van die Ned. Geref. Kerk gebied sou word. In 1938 het hierdie ideaal werklikheid geword en kon die fakulteit met vier dosente en vier studente begin - een dosent per student. Prof. Pellissier was die eerste dekaan.

Vir die volgende sewe jaar het hy die dogmatologiese vakke vir sy verantwoordelikheid gehad, tot sy aftrede aan die einde van 1945 . Gebore op 7 Maart 1881, was hy toe vier-en-sestig jaar oud en sou hy vroeg die volgende jaar vyf-en-sestig word.

Tot op daardie stadium was daar nog geen dosent vir die Rraktiese Teologie nie en is die opleiding in die vakke van die Praktiese Teologie gevolglik onder die vier dosente verdeel. Om hierdie leemte te vul, is Pellissier onmiddellik na sy aftrede weer deur die kerk as kerklike dosent aangestel, met die opdrag om die praktiese vakke te onderrig. Hiermee het hy voortgegaan tot aan die einde van 1952, toe hy reeds een-ensewentig jaar oud was.

Vir die teologiese studente van later geslagte is prof. Pellissier slegs 'n naam en hulle ken hom slegs aan sy foto, waar hy as bejaarde professor 'n waardige en vriendelike oog oor die fakulteit hou. Van die huidige dosente is daar geeneen wat reeds voor 1945 aan die fakulteit studeer het nie, maar feitlik die helfte van hulle het wel onder leiding van Pellissier met die Praktiese Teologie kennis gemaak.

Soos tans nog die geval is, het die voorbereiding en lewering van klaspreke destyds 'n gereelde deel van die akademiese spyskaart 
gevorm. Omdat die fakulteit in daardie stadium nog baie klein was, is verwag dat die studente van al vier jaar die preke moes bywoon. Hierdie preke is in die Pretoria-Ooskerk gehou en omdat studente maar studente is, was die bywoning nie altyd voltallig nie. By geleentheid het prof. Pellissier tydens die bespreking van die preek sy oë oor die aanwesiges laat gaan en hulle aangespreek: "En nou, Here Sewentien ..."

Pellissier was iemand wat vanuit sy rype lewenswysheid en lang bedieningservaring dikwels tydens sy lesings of in antwoord op ' $n$ vraag van 'n student spontaan pittige en diepsinnige opmerkings gemaak het. Dit was meermale juis hierdie opmerkings wat bly steek het lank na die formele inhoud van sy lesings vergeet was. Die kerkhervormer, Maarten Luther, se studente het die gewoonte gehad om aan tafel aantekeninge te maak van sy tafelgesprekke, met die gevolg dat ons vandag nog baie van sy skerpsinnige spontane opmerkings kan lees, waaruit ons hom op 'n ander manier leer ken as wanneer ons sy boeke lees. Dit sou goed gewees het as ons ' $n$ volledige versameling van Pellissier se raak opmerkings kon gehad het. Hy was nie iemand wat ooit veel geskryf of gepubliseer het nie. 'n Boekie oor huisbesoek en 'n klein werkie met die titel "Waarom moet ek kerk toe gaan?" vorm ongeveer sy hele skriftelike nalatenskap. By geleentheid het die N.G. Kerkboekhandel, wat destyds pas tot stand gekom het, by hom aangedring om tog 'n manuskrip te lewer, maar die bykans sewentigjarige hoogleraar het geantwoord dat hy voel hy is nog nie ryp genoeg om te publiseer nie. Hierop het iemand die opmerking gemaak: "Wanneer sal hy dan eendag ryp genoeg wees? Seker eers as hy in die hemel is." Wanneer egter tans, na bykans veertig jaar, teruggekyk word, is dit duidelik watter blywende stempel hierdie groot en beskeie man op sy studente afgedruk het. Vandag nog, wanneer van sy oudstudente met mekaar oor allerlei aspekte van die bediening praat, kan soms gehoor word: "Professor Pellissier het altyd gesê ..." of soms "Prof. Pellie (of Oom Pellie) het altyd gesê ..." (Nodeloos om te noem: So is hy natuurlik nooit deur 'n student aangespreek nie. Daarvoor was die afstand tussen dosent en student destyds veels te groot!)

Sommige van sy diepsinnige opmerkings, wat so spontaan en dikwels op humoristiese wyse aan sy gees ontspring het, het in die geheue van sy studente vasgesteek, maar meeste daarvan is natuurlik lankal vergete. Meer as een student het waarskynlik van hierdie dinge opgeteken, en tydens bloktyd met 'n glimlag weer daarna gekyk - maar wie besit of lees na veertig jaar nog ou aantekeningboeke? Daarom sal dit vir hulle wat prof. Pellissier nog persoonlik geken het seker aangenaam wees om 'n klompie van hierdie opmerkings wat destyds deur skrywer opgeteken is, te lees. Vir diegene wat nooit die voorreg gehad het om 
hierdie werklik groot mens persoonlik te ken nie, kan dit moontlik help om te verstaan waarom hy selfs in sy hoë ouderdom nog daarin kon slaag om met studente te kommunikeer en hulle aandag te hou. Hierdie opmerkings is almal afkomstig van kommentaar wat deur hom gelewer is by die bespreking van klaspreke.

\section{Oor tekskeuse}

"As jy in die gemeente is, moet jy nie net preek oor die teks wat jou pak nie. Dan sal daar dele wees waaroor jy nooit preek nie - en jy kry'n hele skewe affêre."

"'n Lui mens gryp altyd na tekste. Vandag het jy met 'n denkende publiek te doen wat honger is na werklike dinge."

"Hou 'n boekie aan waarin jy al die tekste neerskryf wat jou in jou binnekamer tref. Lees en oorpeins die gedeelte wat jy lees - geen kommentare nie!"

"'n Predikant moet nooit 'n teks soek nie. Die teks moet jou pak. Jy moet 'n aantekeningboekie hê. Die tekste moet hulle hande om jou nek sit en aan jou kleef. As jy gaan teks soek, dan is jy na aan bankrotskap, dan is die bankrotskap al ver gevorderd."

"Sorg dat jy iets kry wat jou pak, want as dit jou pak sal dit jou mense pak, maar as dit jou nie pak nie, sal dit jou mense ook nie pak nie. Maar dit eis studie, want jy moet vol word daarvan."

"Gaan sit, voor jy 'n preek maak, en dink goed na oor watter behoefte daar by jou gemeente is, waarby jy moet aansluit."

By die bespreking van 'n sekere preek het hy omtrent die tekskeuse gesê:

"Daar is roerende emosie in, daar is urgensie in die teks!"

\section{Eksegese en toepassings in die prediking}

Die algemene benadering tot die prediking was destyds geskoei op die onderskeiding tussen explicatio en applicatio: Na die uitleg is oorgegaan tot die toepassing van die teks op die hoorders. Tans word veel meer klem gelê op die feit dat die Woord self aan die woord moet kom en so uitgelê word dat dit in sy aktualiteit tot die mens van die hede spreek. Teen die skerpe skeiding tussen uitleg en toepassing en ' $n$ oormaat van toepassing ten koste van deeglike eksegese het prof Pellissier onvermoeid gewaarsku. "Prediking is eksegese toegepas," het hy geleer, en verder:

"Hou by die eksegese! Anders dwaal jy af op 'n syspoortjie."

"Eksegese is jou assuransie om nie bankrot te raak nie."

"Ons wil net toepas, en ons groot armoede is dat ons nie eksegese wil 
doen nie. Ons sal nooit goed kan toepas as ons nie eksegese doen nie."

Om goeie eksegese te doen, beteken egter nie om slegs baie kommentare te lees en na te praat nie. "Jy moet vol suspisie staan as jy 'n kommentaar lees. Hulle maak baie flaters," het hy by geleentheid gewaarsku.

Die gevaar is altyd daar dat 'n teks op die klank af gekies word en dan los van die konteks waarin dit in die Skrif staan gepreek word. Hieromtrent het hy sy studente geleer: "Elke teks het 'n selofaanomhulsel om, waarin hy adem, en jy mag dit nie breek as jy preek nie" en: "Jou perikoop kleur jou teks."

Ten opsigte van die toepassing van die teks op die gemeente moes hy sê: "Menere, julle is te geneig om toepassings te maak. Die vermaansug is in julle bloed. Julle jeuk om toe te pas. Moenie so baie toepas nie. Die Heiland het nie so baie toegepas nie. Die waarheid maak sy eie toepassing. Maak dit so wonderlik en heerlik dat die persoon verlang om dit self te hè. Laat die waarheid self praat. Ons mense se vel is al baie dik. Hulle wil waarheid hê."

Wanneer die toepassing dan wel gemaak word, geld die volgende reël: "Jy moet jou toepassing sorgvuldig uitdink en weet op wie jy mik."

\section{Vormgewing van die preek}

Om 'n goeie preek te maak en dit dan op besielde wyse te lewer, is iets wat van die predikant tyd vra. Daarom was sy raad: "Jou teks moet twee of drie dae stoom of 'simmer', anders is hy koud. Keer hom om, keer hom om, keer hom om as jy by iemand koffie drink. Dan word hy lekker warm, as jy Sondag daaroor preek. Die beste preek kan soos ' $n$ koue pannekoek platval. As jy op die plaas kom (d.w.s. met 'n buitediens), vra 'n kamer en gaan jou preek weer oor vir 'n halfuur of 'n uur."

Die volgende stukkie goeie raad geld vandag nog presies soos veertig jaar gelede: "lemand het gesê dat jou hoofgedagte so klein moet wees dat jy dit op 'n posseëltjie kan skryf."

"Jy is 'n artist op ontdekkingsreise om uit daardie stof ' $n$ beeld te maak tot eer van God."

"Preek eenmaal per jaar 'n preek bokant die gemeente se kop. Die dominees onderskat die gemeentes. Wees nogtans eenvoudig, diep eenvoudig. Sowel die geleerde as die kind moet iets daaruit kry. Sit jou hart daarin, sit daar 'n boodskap in, dan sal jou hele persoonlikheid daarin wees."

"Dit is maklik om ingewikkeld te preek, maar om eenvoudig te preek is die werk van 'n genie."

"As jy logies en helder preek, sal jy 'n afdruk maak op die gemoed 
van die gemeente. Bene distinguit, bene docet. Die tyd is verby dat jy net 'n klomp tekste deurmekaar kan span."

"Hou jou preek konkreet. 'n Konkrete ding sal die mense meer aantrek as die mooiste abstrakte ding."

"Jy moet soos 'n bloedhond op die spoor van jou teks wees. Hou jou neus op die Iyn. Maak dit dun."

"Moenie afdwaal nie. Die moderne wêreld wil hê jy moet jou neus op die spoor hou - dun en skerp!"

"Die mense wil hê jy moet hulle inlei in die aktualiteit van sake."

"Dit sal 'n vloek vir jou word as jy tekste baie maklik kan verdeel jy word ondiep. Salig is jy as jy sukkel, want dit maak jou ryk. Dit is soos die by in die blom: hoe meer hy woel, hoe ryker word hy belaai."

By geleentheid het 'n student 'n preek gemaak wat uit drie punte bestaan het, waarvan die eerste een baie kort was, terwyl die tweede en derde veel langer was. Hierop was die professor se kommentaar: "Hierdie preek het bepaald 'elephantiases' gehad, want dit het twee baie dik bene." By 'n ander geleentheid was sy kommentaar: "Hierdie preek is oratories verkeerd. Die tweede punt is 'n koue 'sandwich' tussen twee warm punte."

Dit was destyds as vanselfsprekend beskou dat elke preek uit 'n aantal punte bestaan het - gewoonlik drie. Meeste van Pellissier se nagelate preke volg ook hierdie skema. Dat hy dit egter nie as 'n onbreekbare wet beskou het nie, blyk uit sy kommentaar op 'n student se preek, waarin hy ook sy teks so in 'n paar punte verdeel het: "Deur die teks op te breek, het hy dit uit sy heerlike raam gehaal en dit so verlaag. Behou die atmosfeer. Die parfuum en romantiek van die teks is weg. Die teks moet altyd leef in hierdie atmosfeer."

Wanneer wel van indelings gebruik gemaak word, was sy advies egter: "Jy moet jou indelings poleer. Wees soos 'n kunstenaar."

Ten opsigte van die inleiding van die preek, het hy gesê: "Begin jou preek op 'n praktiese wyse, byvoorbeeld: 'Daar is nie een van julle wat hier sit op wie hierdie woord nie van toepassing is nie'."

Oor die noodsaaklikheid van 'n tema was sy mening: "Die formulering van ' $n$ tema is baie goeie oefening vir jou en vir die gemeente."

\section{Die lewering van die preek}

"Preek is praat op sy beste", het hy sy studente geleer.

"Moenie jou preek aframmel nie. Jy moet oor die banke en in die mense kom. Jou taal moet deftig wees. Dit moet nie plat wees nie. Moet ook nie jou taal te hoog maak nie, byvoorbeeld katastrofe, nuanse. Verklaar dit wanneer jy sulke woorde gebruik, byvoorbeeld: Niveau, d.i. vlak." 
"Om gebare te maak, is net ' $n$ teken van armoede van die gees. Wees vaartbelynd in jou prediking. Jy is ' $n$ tolk en ' $n$ tolk moet vaartbelynd wees. 'n Predikant wat skree, wys dat hy swak is."

"As 'n mens iets te sê het, is jy vanself elokwent."

"Daar kom 'n nuwe kwaliteit in jou stem as jy vry voordra."

\section{Oor die afhandeling van die liturgie}

"Moenie die votum te lank maak nie of te veel na 'n gebed laat klink nie ... Die votum moet ' $n$ stelling bevat. Dit is nie ' $n$ gebed nie. Dit moet so ryk wees dat dit 'n seën inhou."

"Lees mooi! Jy kan die lees in die kerk tot 'n effektiewe bediening maak. Elke deel van die erediens is 'n tweespraak. Moenie te tydsaam wees nie, maar moenie jaag nie. Jou voorgebed kan 'n wonderlike bediening wees, ook die voorlees van 'n gesang. Probeer die aksente kry. Jou stem is 'n orrel."

"Moenie 'n slordige dienaar van die Woord wees nie. Lees eers die stukkie by die huis voordat jy dit in die kerk gaan lees."

"Jy kan 'n baie mooi ding maak van jou Skriflesing. Lees dit oor en oor. Lees dit hardop oor."

"Moenie 'asseblief' in jou gebed sê nie. Dis 'n kardinale fout! Sê liewer: 'Mag dit U behaag' of 'Ons smeek U.' Gebruik deftige, eenvoudige, verhewe taal in die gebed."

\section{Oor die prediker self}

Oor die beeld van die predikant wat hy aan sy studente voorgehou het, het meer as een gevleuelde woord van hom gekom. Enkele daarvan is die volgende: "Menere, julle sal sterker predikers word en realiste word as julle net wil dink. Om te dink is die moeilikste ding in die wêreld."

"Jy word wat jy dink! Later beheers daardie dinge jou." preek."

"Die kultuurgehalte, die beskaafdheid van jou gees bepaal jou

"Mens kry alleen oefening in goeie preekstyl deur goeie stiliste te lees en 'n dors na mooi woorde te ontwikkel."

"God is 'n kunstenaar. Alle skoonheid is van Hom."

Met verwysing na die welbekende verhaal van die Duitse prediker, Klaus Harms, wat gewag het dat die Heilige Gees met hom op die kansel sou praat en vir hom sê wat hy aan die gemeente moes sê, maar toe net van die Gees verneem het: "Klaus, jy was lui gewees," het Pellissier gesê: "Moenie maak soos Klaus Harms gemaak het nie ... Christus se eis is verskriklik streng - dit is die liefde self, maar dit is verskriklik streng." 
In hierdie woorde herken ons iets van die mens, prof. Pellissier. Hy was 'n groot en diep mens, 'n denker en 'n student met ' $n$ besondere liefde vir Pascal. In sy gemeentelike bediening was daar waarskynlik baie wat hom nie verstaan het nie, maar as dosent het hy geskitter en het hy bereik wat elke dosent graag sou wou bereik: hy het mense toegerus en gevorm, sodat sy invloed na 'n geslag of meer nog merkbaar is. 